CARADDE: Jurnal Pengabdian Kepada Masyarakat
$\begin{gathered}\text { https://journal.ilininstitute.com/index.php/caradde } \\ \text { Volume 2 | Nomor 2 | Februari | } 2020 \\ \text { e-ISSN: 2621-7910 dan p-ISSN: 2621-7961 }\end{gathered}$

\title{
Inovasi Kue Batik Jember Sebagai Upaya Pengembangan Industri Ekonomi Kreatif Berbasis Kearifan Lokal Jember
}

\section{Astrid Maharani ${ }^{1}$, Seno Sumowo ${ }^{2}$}

\author{
Keywords : \\ inovasi; \\ kue batik Jember; \\ manajemen; \\ akuntansi.
}

\section{Corespondensi Author \\ Akuntansi, Universitas \\ Muhammadiyah Jember \\ Jalan Panjaitan VIII No. 121 Jember \\ Email: \\ astrid.maharani@unmuhjember.ac.id}

\section{History Article}

Received: 09-Oktober-2019;

Reviewed: 117-November-2019;

Accepted: 13-Desember-2019;

Avalaible Online: 16-Januari-2019;

Published: 04-Februari-2020;

\begin{abstract}
Abstrak. Tujuan utama kegiatan ini adalah mengatasi masalah manajemen dan akuntansi yang terjadi pada kedua mitra usaha tersebut. Dengan adanya masalah yang dihadapi tersebut mitra dituntut untuk lebih kreatif dalam hal produk yang akan mereka jual. Program Kemitraan Masyarakat (PKM) yang bersifat problem solving dengan meningkatkan kualitas produksi serta memberikan pendampingan yang tepat pada mitra usaha. Target luaran yang ingin dicapai pada PKM ini yakni (1) inovasi produk, (2) pengadaan alat pendukung produksi kue batik Jember, (3) pelatihan skill membatik, (4) pelatihan dan pendampingan promosi mitra berbasis online dan offline (toko pusat oleh-oleh), (5) template dan pendampingan perhitungan HPP dan pembuatan laporan keuangan berbasis $S A K E M K M$
\end{abstract}

\begin{abstract}
The main purpose of this activity is to overcome management and accounting problems that occur in the two business partners. With the problems faced, partners are required to be more creative in terms of the products they will sell. Community Partnership Program (PKM) which is problem solving by improving the quality of production and providing appropriate assistance to business partners. The output targets to be achieved in this PKM are (1) product innovation, (2) procurement of Jember batik cake production support tools, (3) batik skills training, (4) training and mentoring for online and offline-based partner promotion (central shop by-by), (5) template and accompaniment of HPP calculation and preparation of financial statements based on $S A K E M K M$
\end{abstract}

\section{PENDAHULUAN}

Dewasa ini Indonesia dihadapkan dengan berbagai tantangan yang dihadapi oleh masyarakat. Salah satunya adalah tantangan dalam menghadapi Masyarakat Ekonomi ASEAN, dimana seluruh pasar global masuk ke Indonesia menuntut semua pelaku industri memikirkan pengembangan ekonomi kreatif berbasis kearifan lokal. Salah satu bisnis yang cukup berkembang pesat di Indonesia adalah bisnis kuliner. Menurut Mastuti (2012) dijelaskan bahwa bisnis boga akan terus meningkat karena bisnis ini mencakup kebutuhan primer manusia, yaitu pangan. Beberapa pilihan bisnis kuliner di 
Indonesia cukup beragam. Secara potensial, di Jember sendiri merupakan kota bisnis kuliner cake cukup digandrungi penduduk lokalnya maupun pendatang. Peluang dan potensi industri kecil Jember sampai dengan saat ini masih sangat terbuka untuk di kembangkan. Pasar terbuka lebar. Sektor kuliner masih cukup menjanjikan. Gaya hidup masyarakat dalam konsumsi makanan pun kian beragam. Pemilihan menu makanan tidak lagi soal rasa atau selera, namun juga dapat dari tampilan yang menarik dan kemasan yang unik.

Kabupaten Jember memiliki dua mitra usaha yang bergerak di bidang cake yakni mitra usaha pertama dengan nama Rumah Kue Jember yang berada di Jalan Sriwijaya, Karangrejo dan mitra usaha kedua dengan nama Kue Nafita yang berada di Jalan Karimata, Sumbersari. Rumah Kue Jember merupakan home industry yang bergerak dibidang kuliner terutama pembuatan cake. Mitra usaha ini memulai usaha di tahun 2015 dengan membuat brownies coklat dan cake sifon keju dengan cara pemasaran dari mulut ke mulut dan melalui grup whatapp. Kue Nafita merupakan home industry yang bergerak dibidang kuliner terutama pembuatan cake. Mitra usaha ini memulai usaha di tahun 2013 dengan membuat bolu gulung dan kue tart dengan Cara pemasaran dari mulut ke mulut. Rasa yang dimiliki dari kedua produk mitra sangatlah memanjakan lidah dan tak heran banyak konsumen yang memesan kembali setelah mereka memesan satu kali pada kedua mitra usaha ini.

Dari segi operasional, alat yang digunakan pada kedua mitra usaha masih tergolong sederhana. Kapasitas produksi ratarata kedua mitra adalah 2-3 cake setiap hari kecuali fluktuatif sekali yakni bila tidak terdapat pesanan atau malah ketika banjir pesanan dapat memproduksi 20-30 cake. Dengan alat yang sederhana, mitra memperoleh kendala yakni waktu yang cukup lama untuk melakukan proses produksi. Dari segi pemasaran, meskipun kedua mitra usaha mempunyai cita rasa yang khas, namun keduanya belum memiliki keunikan dalam produk yang ditawarkan. Dari segi akuntansi, belum ada perhitungan HPP yang tepat pada kedua mitra sehingga terkadang mitra tidak sadar bila mengalami kerugian karena kurangnya pencatatan transaksi, pencatatan biaya bahan baku, pencatatan biaya tenaga kerja, dan pencatatan overhead lainnya.

Berdasarkan keterbatasan tersebut, masih cukup sulit bagi kedua mitra usaha cake tersebut untuk mengembangkan usahanya. Hal ini dikarenakan terdapatnya kendala dari segi operasional, pemasaran dan akuntansi maka sangat diperlukan sebuah Program Kemitraan Masyarakat (PKM) yang bersifat problem solving sesuai dengan masalah yang dihadapi oleh kedua mitra usaha tersebut yakni dengan melakukan inovasi terhadap produk yang berbasis kearifan lokal yakni "Inovasi Kue Batik Jember Sebagai Upaya Pengembangan Industri Ekonomi Kreatif Berbasis Kearifan Lokal Jember."

Mitra usaha merupakan jenis UMKM (Usaha Mikro, Kecil, dan Menengah) yang bergerak dibidang kuliner pembuatan kue atau cake. Mitra usaha terdiri yakni Kue Nafita dan Rumah Kue Jember. Berdasarkan survei awal, maka diperoleh beberapa identifikasi masalah yang dihadapi kedua mitra usaha tersebut yakni: (1) Alat dan mesin yang digunakan masih sederhana; (2) Proses produksi masih lama; (3) Citarasa dan menu cake kurang bervariasi dan tergolong masih cake yang sama yang banyak dijual di pasaran; (4) Tidak adanya pembukuan atau praktik akuntansi yang sesuai standar bagi UMKM; (5) Pemasaran produk yang belum optimal.

Berdasarkan identifikasi masalah yang dijumpai pada mitra usaha dapat dipahami bahwa masalah yang dihadapi cukup banyak. Dalam menyelesaikan beberapa masalah tersebut diperlukan adanya justifikasi persoalan prioritas yang disepakati antara Tim pelaksana PKM dan mitra usaha selama pelaksanaan program PKM. Berdasarkan justifikasi persoalan prioritas tersebut, maka tim pelaksana melakukan skala prioritas untuk menyelesaikan masalah tersebut: (1) Skala prioritas pertama ditekankan pada inovasi terhadap citarasa untuk menjadi produk yang unik dan menarik; (2) Skala prioritas kedua ditekankan pada peningkatan strategi pemasaran kepada kedua mitra usaha berbasis online dan offline; (3) Skala prioritas ketiga ditekankan pada perubahan mesin dan alat untuk meningkatkan proses produksi; (4) Skala prioritas keempat ditekankan pada 
perbaikan praktik akuntansi sesuai standar pelaporan keuangan EMKM (Entitas Mikro, Kecil dan Menengah).

\section{Metode}

Dalam rangka menyelesaikan masalah yang ada dalam mitra usaha, maka Tim pelaksana menggunakan metode partisipatif di Program Kemitraaan Masyarakat ini. Penggunaan metode partisipatif menjembatani adanya peran aktif dan keikutsertaan mitra usaha dalam memikirkan solusi yang terjadi selama ini. Solusi diharapkan tidak hanya berasal dari Tim pelaksana tapi karena inisiatif dari mitra usaha yang menghadapi masalah tersebut di lapangan. Peran aktif dari mitra usaha dalam mengatasi masalah yang mereka hadapi melatih dan mengedukasi mitra untuk lebih mengetahui serta menganalisis apa yang menjadi kelebihan dan kelemahan mitra usaha. Hal ini diharapkan dapat membuat terlaksananya Program Kemitraan Masyarakat Inovasi Kue Batik Jember Sebagai Upaya Pengembangan Industri Ekonomi Kreatif Berbasis Kearifan Lokal Jember akan terus berjalan berkesinambungan.

Dengan menggunakan metode pendekatan dan partisipasi mitra dalam pelaksanaan Program Kemitraan Masyarakat, maka langkah yang dilakukan yakni dengan melakukan pelatihan dan pendampingan secara intensif selama kegiatan Program Kemitraan Masyarakat. Sedangkan untuk keberlanjutan program, dapat dipastikan sebelum kegiatan Program Kemitraan Masyarakat berakhir masih tetap dapat dilanjutkan oleh kedua mitra usaha secara mandiri dan berkelanjutan serta kedua mitra usaha dapat merasakan dampak meningkatnya produktifitas kinerja.

\section{HASIL DAN PEMBAHASAN}

\section{Inovasi Produk}

Inovasi adalah transformasi pengetahuan kepada produk,proses dan jasa baru,tindakan menggunakan sesuatu yang baru. Aktivitas inovasi yang kreatif baik itu inovasi proses maupun inovasi produk akan meningkatkan kemampuan perusahaan menciptakan produk yang berkualitas, selanjutnya diharapkan akan meningkatkan keunggulan bersaing perusahaan yang pada akhirnya berdampak pada kinerja perusahaan (Ekawati et al., 2016).

Berdasarkan hasil diskusi dan koordinasi yang dilakukan antara tim pelaksana Program Kemitraan Masyarakat Inovasi Kue Batik Jember Sebagai Upaya Pengembangan Industri Ekonomi Kreatif Berbasis Kearifan Lokal Jember dengan kedua mitra usaha, diperoleh beberapa keputusan yang disepakati akan dilakukan dalam rangka meningkatkan produktivitas mitra usaha dari segi pemasaran antara lain: (a) Pada saat saat diskusi mengenai permasalahan apa saja yang terjadi pada mitra usaha dan tim pelaksana pada tanggal 22 April 2019 disepakati bahwa perlu adanya inovasi pada produk yang saat ini kedua mitra usaha lakukan; (b) Mitra mengusulkan agar inovasi yang dilakukan mudah dilakukan serta membuat suatu keunikan atau ciri khas bagi produk mereka; (c) Tim pelaksana menyarankan untuk menambahkan motif batik Jember pada kedua produk mereka dengan menganalisis adanya peluang kue mereka dapat menjadi alternatif oleh-oleh khas Jember.

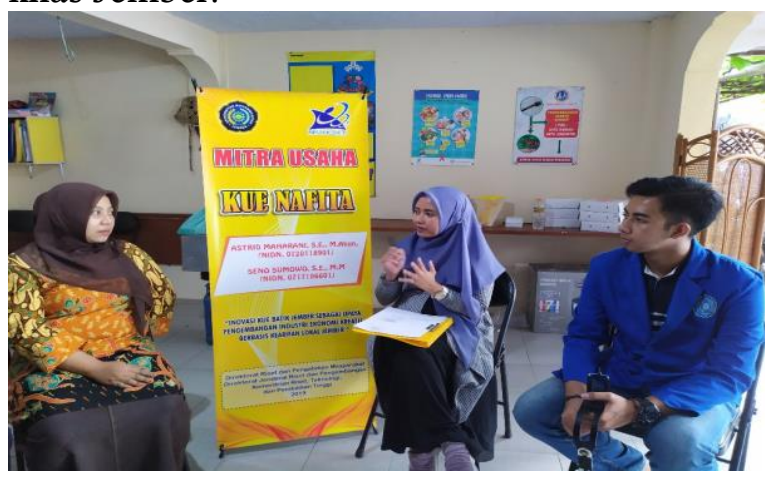

Gambar 1. Diskusi dengan Mitra Usaha

Sebagai tindaklanjut atas diskusi tersebut, maka selaku tim pelaksana Program Kemitraan Masyarakat Inovasi Kue Batik Jember Sebagai Upaya Pengembangan Industri Ekonomi Kreatif Berbasis Kearifan Lokal Jember beberapa kegiatan yang kami lakukan adalah: (1) Pada kedua usaha perlu adanya inovasi yang dilakukan, sehingga produk yang dihasilkan berbeda dengan produk lain yang ada dipasaran. Disepakati bahwa kedua mitra usaha menambahkan motif batik Jember diatas kue yang mereka buat. Dengan adanya penambahan motif batik Jember akan menambah keunikan atau kekhasan produk mereka dan dapat 
menjadikan produk mereka menjadi salah satu oleh-oleh khas Jember; (2) Pada mitra usaha Kue Nafita, awalnya menerima pesanan kue bolu gulung dan kue ulang tahun selanjutnya akan mengembangkan produk, dari kue bolu gulung biasa kemudian ditambahkan motif batik Jember diatas kue bolu gulung. Pada mitra usaha Rumah Kue Jember, awalnya menerima pesanan cake tape selanjutnya akan mengembangkan produk, dari cake tape kemudian ditambahkan motif batik Jember diatas cake tape tersebut.

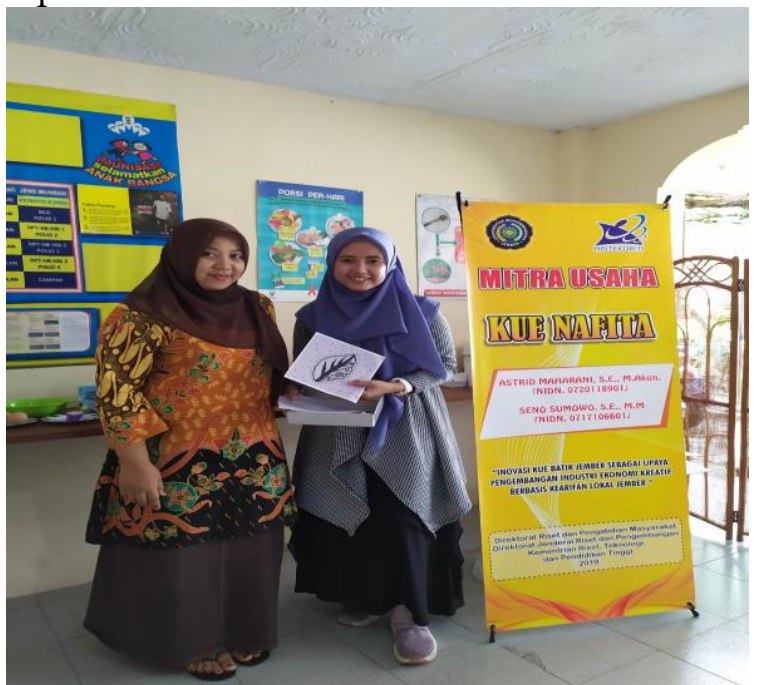

Gambar 2. Kesepakatan Menambah Motif Batik Pada Produk Mitra Usaha

\section{Pengadaan Alat Pendukung Produksi Kue Batik Jember}

Salah satu upaya meningkatkan produktiftas untuk memproduksi suatu produk yaitu dengan pengadaan alat pendukung yang modern untuk proses produksi. Menurut Assauri (2016) adalah suatu kegiatan yang melibatkan tenaga manusia, bahan serta peralatan untuk menghasilkan produk yang berguna.

Berdasarkan hasil diskusi dan koordinasi yang dilakukan antara tim pelaksana Program Kemitraan Masyarakat Inovasi Kue Batik Jember Sebagai Upaya Pengembangan Industri Ekonomi Kreatif Berbasis Kearifan Lokal Jember dengan kedua mitra usaha, diperoleh beberapa keputusan yang disepakati akan dilakukan dalam rangka meningkatkan produktivitas mitra usaha dari segi operasional antara lain: (1) Pada saat diskusi mengenai permasalahan apa saja yang terjadi pada mitra usaha dan tim pelaksana pada tanggal 22 April 2019 disepakati bahwa untuk mitra usaha Kue Nafita dilakukan pengadaan mesin pengaduk adonan atau mixer. Hal ini berasal dari kendala yang dihadapi mitra usaha yakni dari segi operasional, alat yang digunakan pada kedua mitra usaha masih tergolong sederhana yakni mesin pengaduk adonan yang hanya bermuatan 1 liter. Berdasarkan hasil diskusi dengan mitra usaha kapasitas produksi rata-rata kedua mitra adalah 2-3 cake setiap hari kecuali terkadang terdapat hari-hari yang fluktuatif sekali yakni bila tidak terdapat pesanan sama sekali atau malah ketika banjir pesanan dapat memproduksi 2030 cake. Hal ini menyebabkan dengan alat yang sederhana, mitra menghabiskan waktu yang cukup lama untuk melakukan proses pencampuran adonan; (2) Pada saat diskusi mengenai permasalahan apa saja yang terjadi pada mitra usaha dan tim pelaksana pada tanggal 22 April 2019 disepakati bahwa untuk mitra usaha Rumah Kue Jember dilakukan pengadaan mesin oven gas. Hal ini berasal dari kendala yang dihadapi mitra usaha yakni dari segi operasional, mesin oven yang digunakan mitra tergolong sederhana yakni mesin oven listrik. Berdasarkan hasil diskusi dengan mitra usaha kapasitas mesin oven listrik bermuatan 2 loyang berukuran $31 \times 18$ $\mathrm{cm}$. Penggunaan mesin oven listrik yang tergolong memiliki kapasitas yang sedikit menyebabkan mitra usaha membutuhkan waktu yang cukup lama. Proses memanggang merupakan fase paling lama dalam pembuatan kue. Proses memanggang yang terbilang lama ketika terjadi banyak pesanan di Rumah Kue Jember disebabkan karena muatan mesin sedikit dan dalam proses memanggang dibutuhkan waktu kurang lebih 1 jam; (3) Pada saat diskusi mengenai permasalahan apa saja yang terjadi pada mitra usaha dan tim pelaksana pada tanggal 22 April 2019 disepakati bahwa untuk mitra usaha Rumah Kue Jember dilakukan pengadaan generator set. Hal ini berasal dari kendala yang dihadapi oleh kedua mitra usaha yakni ketika terjadi pemadaman listrik menyebabkan kedua mitra tidak dapat melakukan atau melanjutkan proses produksi. $\mathrm{Hal}$ ini menyebabkan kedua mitra membatalkan pesanan pada hari tersebut yang berdampak pada kekecewaan konsumen karena pemesanan pada hari tersebut 
dibatalkan. Selain kekecewaan konsumen, hal ini pula berdampak pada kerugian materiil yang dialami oleh kedua mitra usaha tersebut.

Sebagai tindaklanjut atas diskusi tersebut, maka selaku tim pelaksana Program Kemitraan Masyarakat Inovasi Kue Batik Jember Sebagai Upaya Pengembangan Industri Ekonomi Kreatif Berbasis Kearifan Lokal Jember beberapa kegiatan yang kami lakukan adalah sebagai berikut; (4) Melakukan pembelian atau pengadaan mesin pengaduk adonan atau mixer. Pengadaan atau pembelian mesin pengaduk adonan atau mixer didasari adanya kebutuhan untuk peningkatan produktivitas mitra usaha. Semula mixer yang dimiliki oleh mitra usaha Kue Nafita hanya dapat menampung adonan 1 Liter dengan mesin pengaduk adonan atau mixer yang dibeli pada tanggal 20 Juni 2019 dapat menampung 8 Liter adonan cake; (5) Melakukan pembelian atau pengadaan mesin oven gas. Pengadaan atau pembelian mesin oven gas didasari adanya kebutuhan untuk meningkatkan kapasitas pada proses pemanggangan cake tape pada mitra usaha Rumah Kue Jember. Semula oven yang dimiliki oleh mitra usaha Rumah Kue Jember hanya bermuatan 2 loyang berukukuran $31 \mathrm{x}$ $18 \mathrm{~cm}$ dengan oven yang dibeli pada tanggal 2 Juli 2019 dapat menampung 6 loyang berukuran 40 x $40 \mathrm{~cm}$; (6) Melakukan pembelian atau pengadaan mesin generator set. Pengadaan atau pembelian mesin generator set didasari kebutuhan kedua mitra usaha untuk dapat menyelesaikan seluruh pesanan setiap harinya dengan tepat waktu meskipun terjadi pemadaman listrik. Semula apabila terjadi pemadaman di daerah mitra usaha, maka kedua mitra usaha membatalkan pesanan yang menyebabkan kekecewaan konsumen dan kerugian materiil yang dihadapi oleh mitra usaha. Mesin generator set berbahan bakar bensin membuat mitra akan tetap dapat terus berproduksi dan menyelesaikan seluruh pesanan tepat waktu.

\section{Pelatihan Membatik dengan Media Kue}

Berdasarkan hasil diskusi dan koordinasi yang dilakukan antara tim pelaksana Program Kemitraan Masyarakat Inovasi Kue Batik Jember Sebagai Upaya Pengembangan Industri Ekonomi Kreatif
Berbasis Kearifan Lokal Jember dengan kedua mitra usaha, diperoleh beberapa keputusan yang disepakati akan dilakukan dalam rangka meningkatkan inovasi mitra usaha antara lain: (1) Memberikan edukasi dan pemahaman kepada karyawan mitra usaha terkait mengapa suatu usaha perlu melakukan inovasi produk; (2) Memberikan gambaran mengenai batik Jember termasuk beragam motif batik Jember; (3) Memberikan edukasi dan pemahaman kepada mitra usaha terutama kepada karyawan kedua mitra usaha terkait mekanisme dan tahapan membatik dengan media kue.

Sebagai tindaklanjut atas diskusi tersebut, maka selaku tim pelaksana Program Kemitraan Masyarakat Inovasi Kue Batik Jember Sebagai Upaya Pengembangan Industri Ekonomi Kreatif Berbasis Kearifan Lokal Jember beberapa kegiatan yang kami lakukan adalah melakukan pelatihan mengenai membatik dengan media kue dengan rincian: (1) Materi yang disampaikan oleh Tim Pelaksana menjelaskan mengenai perlunya inovasi dalam suatu produk; (2) Inovasi tersebut dicerminkan dengan menambahkan motif batik Jember pada produk mereka saat ini; (3) Materi tersebut memberikan edukasi dan motivasi bagi mitra usaha yang dihadiri pekerja masing-masing mitra usaha dengan total peserta 10 orang dan 5 orang berasal dari tim pelaksana dosen dan mahasiswa Fakultas Ekonomi dan Bisnis Universitas Muhammadiyah Jember; (4) Pada pelatihan tersebut tidak hanya menjelaskan teori saja, namun juga langsung mempraktekkan bagaimana cara membatik dengan media kue.

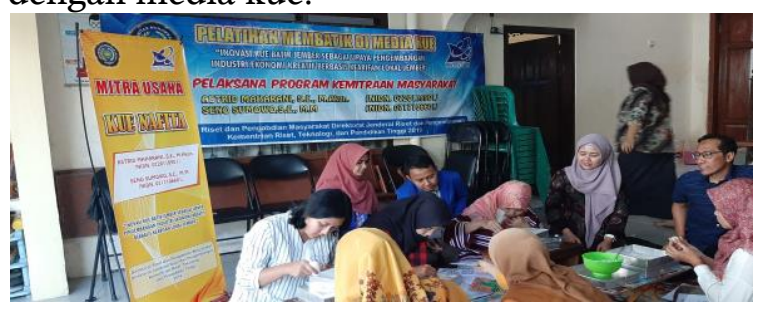

Gambar 3. Pelaksanaan Pelatihan Membatik Di Media Kue

Pelatihan berdurasi 3 jam dengan antusisme pekerja untuk bertanya hal yang berkaitan dengan proses pembuatan cake bermotif batik Jember. 


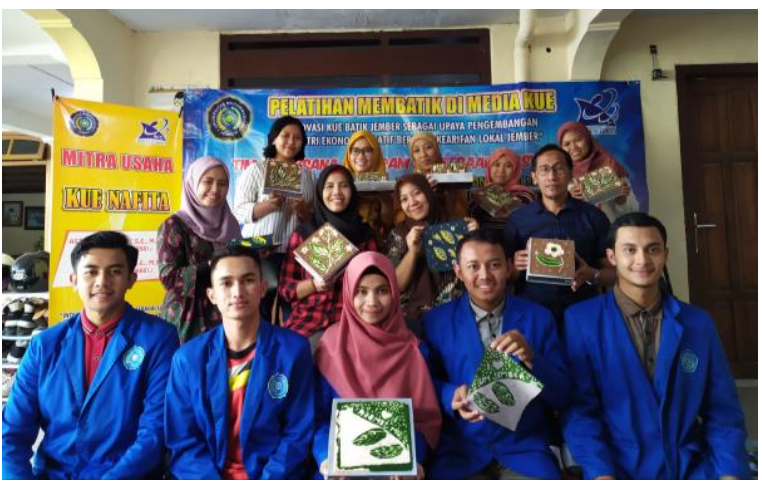

Gambar 4. Hasil Membatik di Media Kue

\section{Peningkatan Strategi Pemasaran Berbasis Online}

(2014), pemasaran berbasis online menggambarkan usaha perusahaan untuk memasarkan produk dan jasa, serta membangun hubungan dengan pelanggan melalui internet. Menurut Armstrong dan Kottler (2014), E-Marketing adalah sisi pemasaran dari E-Commerce, yang merupakan kerja dari perusahaan untuk mengkomunikasikan sesuatu, mempromosikan, dan menjual barang dan jasa melalui internet. Pengguna internet marketing dapat dengan mudah mengakses informasi dimana saja dengan komputer dan smartphone yang terhubung ke internet, jadinya di era industri 4.0 yang serba online saat ini pemasaran melalui media internet itu sangat berpeluang besar dikarenakan banyaknya masyarakat yang menggunakan smartphone dan internet untuk mencari informasi dan membeli suatu produk, dan pada tiap tahunnya usaha perdagangan melalui media online ini slalu meningkat dari tahun 2015-2019 ini. Proses pemasaran internet marketing yang paling sering dilakukan dan sudah terbukti efektif bagi para pebisnis yaitu, membuat website atau blog khusus untuk bisnis, pemasaran melalui media sosial seperti Facebook, Instagram, YouTube.

Berdasarkan hasil diskusi dan koordinasi yang dilakukan antara tim pelaksana Program Kemitraan Masyarakat Inovasi Kue Batik Jember Sebagai Upaya Pengembangan Industri Ekonomi Kreatif Berbasis Kearifan Lokal Jember dengan kedua mitra usaha, diperoleh beberapa keputusan yang disepakati akan dilakukan dalam rangka meningkatkan pemasaran mitra usaha antara lain.

1. Pembuatan website bagi mitra usaha yang semenarik mungkin agar informasi tentang produk mitra usaha lebih meluas lagi.

2. Penggunaan media sosial seperti Facebook dan Instagram agar memudahkan untuk melakukan promosi dan penjualan, karena kedua media sosial tersebut banyak di gunakan oleh masyarakat.

3. Pengelelolaan seluruh aplikasi internet marketing agar penjualan menggunakan media online terus berkembang dan berkelanjutan untuk menarik minat konsumen.

Sebagai tindaklanjut atas diskusi tersebut, maka selaku tim pelaksana Program Kemitraan Masyarakat Inovasi Kue Batik Jember Sebagai Upaya Pengembangan Industri Ekonomi Kreatif Berbasis Kearifan Lokal Jember beberapa kegiatan yang kami lakukan adalah sebagai berikut.

1. Membuat website resmi mitra usaha demi meningkatkan informasi yang komperhensif kepada konsumen. Website mengulas mengenai sejarah mitra usaha, inovasi produk, harga, dan cara pemesanan kepada calon konsumennya.

2. Membuat situs bisnis dari media sosial facebook dan instagram sebagai media promosi dan penjualan produk, agar konsumen dapat bisa membeli dan lebih mudah mencari informasi tentang produk. Dan juga dikarenakan ke dua media sosial tersebut memiliki fitur halaman bisnis yang mampu memberi peluang bagi penggunanya untuk berbisnis.

3. Menghubungkan semua media sosial (facebook dan instagram) ke website resmi yang sudah di buat sebelumnya.

4. Memberi pendampingan dan penjelasan mengenai pembuatan konten yang menarik, promosi di media sosial, mencari target konsumen, dan pelatihan tentang penggunaan pelayanan penjualan online menggunakan website, facebook, dan instagram.

\section{Peningkatan Strategi Pemasaran Berbasis Offline}


Menurut Assauri (2016) yaitu strategi pemasaran adalah serangkaian tujuan dan sasaran, kebijakan dan aturan yang memberi arah kepada usaha-usaha pemasaran perusahaan dari waktu ke waktu, pada masing-masing tingkatan dan acuan serta alokasinya, terutama sebagai tanggapan perusahaan dalam menghadapi lingkungan dan keadaan persaingan yang selalu berubah. Menurut McCarthy dalam Tjiptono dan Chandra (2012), aspek pokok dalam pemasaran yakni produk (product), harga (price), promosi (promotion), dan lokasi (place). Dan juga apabila suatu usaha menjalin kerjasama dengan kelompok UMKM yang berada di daerahnya maka akan semakin meningkat dari segi penjualannya dan promosinya sehingga lebih mudah untuk memasarkan produk tersebut, dan agar UMKM meningkat jumlah penjualannya dan sesuai target maka harus menggunakan strategi pemasaran 4P. Berikut penjabaran dari aspek pokok dalam pemasaran 4P : Product (Produk), Price (Harga), Place (Lokasi) dan Promotion (Promosi) yang terdapat dalam kerangka marketing mix.

\section{Product}

Setiap UMKM harus bisa menentukan produk apa yang menjadi andalannya dan bagaimana cara mengembangkan produk andalannya tersebut. Misalnya dengan menambah varian rasa, varian ukuran, varian bentuk dan juga varian kemasannya. Hal yang paling penting dan krusial yang harus dijaga adalah kualitas dari produk andalan. Seorang UKM jangan pernah melakukan perubahan rasa, bentuk, warna, ukuran dan kualitas tanpa melakukan info atau pemberitahuan ke pelanggan sebelumnya. Karena perubahan produk yang tiba - tiba akan menyebabkan pelanggan kecewa dan apabila pelanggan kecewa hal tersebut akan berlanjut dan akan berakibat ke penurunan penjualan.

2. Price

Penentuan harga produk sangat menentukan dalam kesuksesan proses penjualan. Harga adalah sejumlah uang yang harus dibayar konsumen untuk mendapatkan sebuah produk atau jasa. Dalam bauran pemasaran, harga merupakan salah satu faktor penting yang mempengaruhi pemasaran suatu produk. Tinggi rendahnya harga selalu menjadi perhatian utama para konsumen saat mereka mencari suatu produk.
Sehingga harga yang ditawarkan menjadi bahan pertimbangan khusus, sebelum mereka memutuskan untuk membeli barang maupun menggunakan suatu jasa. Dari kebiasaan para konsumen, dapat disimpulkan bahwa strategi penetapan harga sangat berpengaruh terhadap penjualan maupun pemasaran produk yang ditawarkan.

\section{Place}

Dalam strategi pemasaran, adanya pemilihan lokasi usaha yang strategis menjadi salah satu faktor yang mempengaruhi kesuksesan pemasaran dari sebuah usaha. Semakin strategis lokasi usaha yang dipilih, semakin tinggi pula tingkat penjualan dan berpengaruh terhadap kesuksesan sebuah usaha. Begitu juga sebaliknya, jika lokasi usaha yang dipilih tidak strategis maka penjualan pun juga tidak akan terlalu bagus. Untuk itu sebelum Anda memulai sebuah usaha, pilih terlebih dahulu tempat usaha yang paling tepat untuk pemasaran usaha Anda. Lakukan riset dan bandingkan beberapa pilihan tempat sebelum akhirnya Anda menentukan lokasi yang paling strategis bagi usaha Anda.

\section{Promotion}

Kegiatan promosi bisnis merupakan bagian dari strategi pemasaran yang sangat dibutuhkan sebuah usaha, baik usaha kecil maupun usaha yang sudah berkembang besar. Sebelum mengetahui metode ataupun strategi promosi yang sering digunakan para pelaku bisnis, yang dimaksud dengan promosi adalah kegiatan pendukung strategi pemasaran yang sengaja diadakan untuk mengingatkan para konsumen mengenai produk atau jasa dengan brand tertentu. Strategi-pemasaran-bisnis-ukm Strategi promosi sering digunakan sebagai salah satu cara untuk meningkatkan permintaan atau penjualan barang dan jasa yang ditawarkan, sehingga dapat meningkatkan laba yang diperoleh. Selain itu kegiatan promosi juga memberikan kemudahan dalam merencanakan strategi pemasaran selanjutnya, karena biasanya kegiatan promosi dijadikan sebagai cara berkomunikasi langsung dengan calon konsumen. Sehingga kita dapat memperoleh informasi akurat dari para konsumen, mengenai respon produk yang kita tawarkan. Berikut beberapa manfaat lain dari adanya kegiatan promosi : Mengetahui produk yang diinginkan para konsumen. Mengetahui tingkat kebutuhan konsumen akan suatu 
produk. Mengetahui cara pengenalan dan penyampaian produk hingga sampai ke konsumen. Mengetahui harga yang sesuai dengan kondisi pasaran. Mengetahui strategi promosi yang tepat kepada para konsumen. Mengetahui kondisi persaingan pasar dan cara mengatasinya. Menciptakan image sebuah produk dengan adanya promosi.

Berdasarkan hasil diskusi dan koordinasi yang dilakukan antara tim pelaksana Program Kemitraan Masyarakat Inovasi Kue Batik Jember Sebagai Upaya Pengembangan Industri Ekonomi Kreatif Berbasis Kearifan Lokal Jember dengan kedua mitra usaha, diperoleh beberapa keputusan yang disepakati akan dilakukan dalam rangka meningkatkan pemasaran mitra usahay: (1) Melakukan pendampingan kepada mitra usaha terkait aspek pokok dalam pemasaran menggunakan strategi pemasaran 4P : Product, Price, Place, dan Promotion; (2) Melakukan pendampingan kepada mitra usaha untuk dapat melakukan pemasaran secara offline dengan membina kerjasama dengan pusat oleh-oleh di Jember.

Sebagai tindaklanjut atas diskusi tersebut, maka selaku tim pelaksana Program Kemitraan Masyarakat Inovasi Kue Batik Jember Sebagai Upaya Pengembangan Industri Ekonomi Kreatif Berbasis Kearifan Lokal Jember beberapa kegiatan yang kami lakukan adalah: (1) Mitra melakukan pemetaan target pemasaran secara offline yang selama ini telah berjalan; (2) Berdasarkan saran tim pelaksana, mitra usaha melakukan perluasan pangsa pasar dengan pemasaran offline yang dilakukan dengan membangun kerjasama dengan pusat oleh-oleh khas Jember.

\section{Pelatihan Perhitungan HPP}

Dari segi akuntansi biaya, mitra ini masih dalam keadaan tidak dapat menghitung harga pokok produksi, sehingga perlunya pelatihan perhitungan harga pokok produksi agar segala jenis biaya produksi dapat dikendalikan serendah mungkin tanpa menurunkan kualitas produk yang dihasilkan. Harga Pokok Produksi adalah biaya barang yang dibeli untuk diproses sampai selesai, baik sebelum maupun selama periode akuntansi berjalan (Sofia dan Septian, 2017).
Perusahaan atau mitra harus menghitung harga pokok produksi suatu barang karena sangat penting untuk pelaporan keuangan perusahaan atau mitra tersebut. Jika mitra salah ketika menentukan harga pokok produksi, bisa jadi mitra merugi karena ternyata biaya yang dikeluarkan tidak sebanding dengan pendapatan yang diperoleh. Untuk menghindari kesalahan dalam menentukan harga pokok produksi, maka tim pelaksana Program Kemitraan Masyarakat (PKM) Inovasi Kue Batik Jember Sebagai Upaya Pengembangan Industri Ekonomi Kreatif Berbasis Kearifan Lokal Jember memberikan pelatihan kepada mitra mengenai komponen atau biaya apa saja yang harus ada dalam melakukan perhitungan tersebut.

Semua komponen atau biaya tersebut iyalah biaya persedian. Biaya persediaan yaitu semua biaya produk yang dianggap sebagai aktiva dalam neraca ketika terjadi dan selanjutnya menjadi harga pokok penjualan ketika produk itu dijual. Harga pokok penjualan mencakup semua biaya produksi yang terjadi untuk membuat barang yang terjual. Biaya produksi dapat digolongkan menjadi tiga yaitu:

1. Biaya bahan baku adalah biaya perolehan semua bahan yang pada akhirnya akan menjadi bagian dari objek biaya (barang dalam proses dan kemudian barang jadi) dan yang dapat ditelurusi ke objek biaya dengan cara yang ekonomis.

2. Biaya tenaga kerja langsung atau upah langsung adalah biaya yang dibayarkan kepada tenaga kerja langsung. Istilah tenaga kerja langsung digunakan untuk menunjuk tenaga kerja (buruh) yang terlibat secara langsung dalam proses pengolahan bahan baku menjadi barang jadi.

3. Biaya overhead pabrik (biaya produksi tidak langsung) adalah seluruh biaya manufaktur yang terkait dengan objek biaya namun tidak dapat ditelusuri ke objek biaya (barang dalam proses dan kemudian barang jadi) dengan cara yang ekonomis.

Ketiga komponen biaya di atas penting dalam penentuan harga pokok produksi yang di perlukan mitra untuk diketahui agar mitra dapat mengendalikan semua jenis biaya di atas dengan serendah mungkin tanpa 
menurunkan nilai kualitas produk yang dihasilkan. Dalam hal ini tim pelaksana Program Kemitraan Masyarakat (PKM) Inovasi Kue Batik Jember Sebagai Upaya Pengembangan Industri Ekonomi Kreatif Berbasis Kearifan Lokal Jember melalui diskusi dan koordinasi dengan mitra dapat diambil beberapa keputusan untuk melakukan pelatihan perhitungan harga pokok produksi serta memberikan wawasan kepada mitra usaha mengenai harga pokok produksi.

Dalam pelatihan perhitungan harga pokok produksi materi yang akan dijelaskan kepada mitra usaha yaitu mengenai apa itu harga pokok produksi, mengapa harga pokok produksi itu penting, apa manfaat dari perhitungan harga pokok produksi bagi mitra, dan bagaimana cara menghitung harga pokok produksi. Dengan adanya pelatihan mengenai perhitungan harga pokok produksi ini maka: (a) Mitra dapat mengetahui dan mengendalikan semua jenis biaya; (b) Bertambahnya wawasan mengenai harga pokok produksi; (c) Mitra dapat membuat dan menghitung harga pokok produksi untuk pelaporan keuangannya.

\section{Pelatihan Laporan Keuangan Berbasis EMKM}

Akuntansi adalah proses sistematis untuk mengolah transaksi menjadi informasi keuangan yang bermanfaat bagi para penggunanya (Warsono,2010). Praktek nyata yang dilakukan oleh pelaku usaha Kue Batik Jember dalam mengatur keuangan masih sangat lemah. Kami menemukan bahwa perhitungan keuangan pada usaha ini masih berupa pembukuan yang sederhana dan belum teratur, sehingga sulit untuk melakukan pengambilan keputusan dan pembuatan kebijakan-kebijakan guna meningkatkan usahanya. Permasalahan yang paling mendasar dalam kegiatan akuntansi adalah tidak adanya pemisahan antara uang pribadi pemilik dengan modal usaha. Oleh karena itu, sulit untuk menentukan laba yang sebenar-benarnya. Cara untuk mengetahui laba yang diperoleh yaitu dengan mengikuti proses pembuatan laporan keuangan yang sesuai dengan standar yang berlaku. Sejak 1 Januari 2018 telah diberlakukan secara efektif Standar Akuntansi Keuangan Entitas Mikro, Kecil dan Menengah (SAK-EMKM) oleh Ikatan Akuntan Indonesia (IAI). SAK EMKM hanya mengatur transaksi yang bersifat umum. SAK EMKM memiliki dasar pengukuran murni menggunakan biaya historis, sehingga EMKM cukup mencatat aset, liabilitas sebesar biaya perolehan (Mardiasmo, 2016).

Berdasarkan tingkat pemahaman tentang akuntansi yang masih rendah, tim pelaksana Program Kemitraan Masyarakat (PKM) Inovasi Kue Batik Jember Sebagai Upaya Pengembangan Industri Ekonomi Kreatif Berbasis Kearifan Lokal Jember melaksanakan kegiatan berupa Pelatihan Penyusunan Laporan Keuangan berbasis EMKM (Entitas Mikro Kecil dan Menengah) dengan rangkaian penyampaian materi sebagai berikut: (1) Pendahuluan/Pengantar Akuntansi; (2) tandar penyusunan laporan leuangan yang berlaku yaitu SAK EMKM; (3) Praktik penyusunan laporan keuangan EMKM.

Pada pengantar akuntansi tim pelaksana menjelaskan pentingnya perlakuan akuntansi dalam bentuk penyusuanan laporan keuangan bagi UMKM. Pada mulanya mereka menganggap akuntansi adalah hal yang sulit, rumit, merepotkan dan menghabiskan banyak waktu. Sehingga perlunya materi penguatan tentang pentingnya akuntansi bagi UMKM. Kemudian kami juga menjelaskan kepada karyawan pemahaman terkait SAK EMKM yang berlaku. Selanjutnya adalah proses pencatatan akuntansi yang bermula dengan aktivitas investasi (memulai usaha), transaksi pembelian bahan baku, pembelanjaan/pengeluaran, pemasukan dll. Terakhir kami mempraktekkan pembuatan laporan keuangan berbasis EMKM. Dengan antusias dari karyawan kegiatan pelatihan ini dapat menambah wawasan karyawan mengenai akuntansi sehingga dapat memberi kemajuan Usaha Kue Batik Jember. Dengan begitu hasil dari laporan pertanggungjawaban kinerja dalam bentuk laporan keuangan berbasis EMKM dapat berguna bagi pihak internal yakni untuk pengambilan keputusan dengan cepat dan tepat juga bagi pihak eksternal seperti kreditor, investor dan pengguna yang lainnya.

\section{SIMPULAN DAN SARAN}

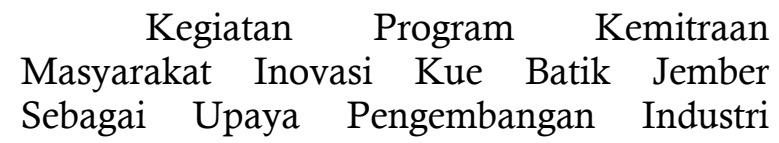


Ekonomi Kreatif Berbasis Kearifan Lokal Jember yang telah terlaksana, dapat disimpulkan yaitu: (1) Dalam upaya meningkatkan pemasaran pada kedua mitra usaha perlu adanya inovasi yang dilakukan, yakni dengan menambahkan motif batik Jember diatas kue yang mereka buat. Dengan adanya penambahan motif batik Jember akan menambah keunikan atau kekhasan produk mereka dan dapat menjadikan produk mereka menjadi salah satu oleh-oleh khas Jember; (2) Dalam upaya meningkatkan produktivitas dengan memperbaiki dari segi operasional, yakni dengan pembelian alat pendukung pembuatan kue batik Jember seperti mesin pengaduk adonan (mixer), mesin oven gas, dan generator set; (3) Dalam upaya membekali inovasi yang akan dilakukan dengan penambahan motif baik pada produk mitra usaha dilakukan pelatihan mengenai membatik pada media kue; (4) Dalam upaya peningkatan pemasaran dilakukan pendampingan dan pembuatan jaringan baik pemasaran secara online maupun offline. Pemasaran online yakni dengan pembuatan website dan media sosial, sedangkan pemasaran offline yakni dengan memasarkan produk mitra usaha pada toko pusat oleh-oleh Jember; (5) Dalam upaya peningkatan pembukuan, dilakukan pelatihan perhitungan HPP dan pelatihan penyusunan Laporan Keuangan berbasis SAK EMKM.

Berdasarkan kegiatan yang telah berlangsung pada kedua mitra usaha maka kedua mitra telah kooperatif dalam membantu pelaksanaan Program Kemitraan Masyarakat Inovasi Kue Batik Jember Sebagai Upaya Pengembangan Industri Ekonomi Kreatif Berbasis Kearifan Lokal Jember. Beberapa saran atas kegiatan yang telah dilakukan yakni: (1) Penggunaan alat baru membutuhkan perawatan yang mungkin perlu adanya service secara berkala atas penggunaan alat modern tersebut; (2) Pemasaran secara online yang dilakukan masih harus mendapatkan pendampingan agar lebih optimal dan berkesinambungan.

\section{DAFTAR RUJUKAN}

Armstrong, G., Adam, S., Denize, S., \& Kotler, P. (2014). Principles of marketing. Pearson Australia.
Assauri, S. (2016). Manajemen Operasi Produksi Pencapaian Sasaran Organisasi Berkesinambungan. Jakarta: PT Rajagafindo Persada.

Ekawati, S., \& Puspitowati, I. (2016). Pengaruh Manajemen Pengetahuan Dan Inovasi Terhadap Kinerja Perusahaan UKM Di Jakarta. Conference on Management and Behavioral Studies.

Mastuti, I. (2012). Virus Mompreneur! Kiatkiat Menjadi Ibu dengan Memulai dan Mengembangkan Bisnis Sendiri. Jakarta: Gramedia Pustaka Utama.

Tjiptono, F. \& Chandra, G. (2012). Pemasaran Strategik Edisi 2. Yogyakarta: Andi.

Warsono, S., Murti, E., Ridha, A., \& Darmawan, A. (2010). Akuntansi UMKM ternyata mudah dipahami dan dipraktikkan. Yogyakarta: Asgard Chapter.

Wong, S. Y., Susilawati, C., Miller, W., \& Mardiasmo, A. (2016). Enhancing information about sustainability features for sustainable housing delivery. In Proceedings of the 10th World Congress on Engineering Asset Management (WCEAM 2015)(pp. 407414). Springer, Cham. 